\title{
Um poema de Marià Vayreda i Vila e duas versões
}

\author{
Luciana Carvalho
}

Marià Vayreda i Vila, escritor e artista catalão (1853-1903), foi exilado político em Paris devido à participação na Terceira Guerra Carlista. Na literatura, ele é considerado um dos modernizadores da língua catalã. Sua principal obra, La Punyalada (1903), de veia realista, é considerada um dos grandes romances catalães.

\author{
A la platja del Llaner \\ solen fer la migdiada \\ les barques en dolç va i ve \\ i cada una emmirallada \\ en l'espill del mar més blau \\ troba el repòs i la pau. \\ On the beach of Llaner \\ we doze away \\ seeing the boats coming and going \\ each an emerald \\ on the horizon beyond the sea even more blue \\ we find peace and quiet.
}


Luciana Carvalho. Um poema de Marià Vayreda $i$ Vila e duas versões

Na praia de Llaner

adormecemos

vendo o doce ir e vir dos barcos

cada um, uma esmeralda

no horizonte além do mar mais azul

encontramos a paz e o sossego. 